\title{
Isolation, structure elucidation, and antidiabetic test of vicanicin compound from lichen Teloschistes flavicans
}

\author{
Maulidiyah Maulidiyah $^{1 *}$, Akhmad Darmawan², Asriani Hasan¹, Dwiprayogo Wibowo², La Ode Agus Salim ${ }^{1}$, Ansharullah \\ Ansharullah $^{4}$, Faizal Mustapa ${ }^{5}$, Ishmah Farah Adiba Nurdin ${ }^{6}$, Muhammad Nurdin ${ }^{1}$ \\ ${ }^{1}$ Department of Chemistry, Faculty of Mathematics and Natural Sciences, Universitas Halu Oleo, Kendari, Indonesia. \\ ${ }^{2}$ Research Center for Chemistry, Indonesian Institute of Sciences, Tangerang, Indonesia. \\ ${ }^{3}$ Department of Pharmacy, Faculty of Sciences and Technology, Institut Teknologi dan Kesehatan Avicenna, Kendari, Southeast Sulawesi, Indonesia. \\ ${ }^{4}$ Department of Food Science Technology, Faculty of Agriculture, Universitas Halu Oleo, Kendari, Indonesia. \\ ${ }^{5}$ Department of Aquaqulture, Faculty of Sciences and Technology, Institut Teknologi dan Kesehatan Avicenna, Kendari, Indonesia. \\ ${ }^{6}$ Faculty of Medicine, Universitas Halu Oleo, Kendari, Indonesia.
}

\begin{tabular}{l}
\hline ARTICLE INFO \\
\hline Received on: 10/06/2020 \\
Accepted on: 30/08/2020 \\
Available online: 05/11/2020 \\
\\
\hline Key words: \\
Lichen, Teloschistes flavicans, \\
antidiabetic, $\alpha$-glucosidase, \\
vicanicin.
\end{tabular}

\begin{abstract}
Teloschistes flavicans is a lichen genus of the Teloschistaceae family with the orange-yellow color making it a very distinctive species. Recently, T. flavicans has been used as a natural medicinal ingredient because it contains several secondary metabolites to treat diseases. Thus, the aim of this study is to show the antidiabetic activity and isolation of secondary metabolite compounds from $T$. flavicans. Extraction, separation, and purification were conducted by using acetone solvent and separation was conducted by using column gravity combined with thin layer chromatography. Based on these results, we discovered the secondary metabolites of $T$. flavicans by the appearance of pure white crystal needles. Moreover, it was tested using liquid chromatography-mass spectroscopy/MS, Fourier-transform infrared spectroscopy, and $1 \mathrm{D}-\mathrm{NMR}$ spectroscopy $(1 \mathrm{H}$ and $13 \mathrm{C})$ and comparison with several studies shows that the secondary metabolite vicanicin was obtained with the molecular formula $\mathrm{C}_{18} \mathrm{H}_{16} \mathrm{Cl}_{2} \mathrm{O}_{5}$. Subsequently, the antidiabetic activity of T. flavicans was investigated by estimating the level of non-enzymatic antioxidants from $\alpha$-glucosidase with an $\mathrm{IC}_{50}$ value of $197.04 \mu \mathrm{g} / \mathrm{ml}$. This research provides a perspective on the natural products of lichen T. flavicans, which have the potential as antidiabetic medicine.
\end{abstract}

\section{INTRODUCTION}

A recent study on natural phytopharmacy has attracted researchers to explore new medicines based on various types of medicinal plants, such as their uniqueness, benefits, and local wisdom (habitat and endemic location) (Pit'ay et al., 2019; Rohman et al., 2019). One of the types, local wisdom, has a unique appeal and exploration to observe the potential of medicinal plants from various countries (Rahardi, 2020). Indonesia is a mega-biodiverse country with a diversity of plants and organisms that have a high potential for exploration of natural

\section{"Corresponding Author}

Maulidiyah Maulidiyah, Department of Chemistry, Faculty of Mathematics and Natural Sciences, Universitas Halu Oleo, Kendari, Indonesia. E-mail:maulid06@yahoo.com products as medicinal ingredients (Sosilawaty, 2020; Yuniati et al., 2019). What is more, Indonesia is a tropical country that easily grows a variety of plants due to high sun exposure for high photosynthesis.

At present, the exploration of secondary metabolites from the plant has been studied based on the classification of algae and fungi because it produces the same secondary metabolite product (O'Neill, 2020; Selvakumar et al., 2020). It was identified for studying several active compounds from medicinal plants and will be developed for the basis of producing synthetic drugs (Yanuar et al., 2011). One of the unique organisms of lichen has attracted attention because it contains various types of secondary metabolites that are medicinal (Huneck and Yoshimura, 1996). Particularly, its symbiotic mutualism with algae (cyanobacteria) and fungi is very essential for exploring natural materials (Lutzoni et al., 2001; Maulidiyah et al., 2011). 
According to the latest research studies by LondoñeBailon et al. (2019) and Nguyen et al. (2020), the lichen contains bioactive compounds, such as eumitrins C-E (xanthones), alkaloids, flavonoids, and terpenoids, that have high antibacterial, antioxidant, and cytotoxic activity. In our previous study, we also reported on bioactive compounds, such as 3-[1'-(2",3"-dihydroxy-phenyl)-propyl]-7-hydroxychroman-4-one (Maulidiyah et al., 2018), (5E,6E) 5-ethylidene7-formyl-6,7-hydroxy methyl hept-6-enoate (Maulidiyah et al., 2016b), Eumitrin A1 (Maulidiyah et al., 2015), 2'-hydroxy-1'(4-hydroxyl-5-methoxy-2-methyl-phenyl)-etone (Maulidiyah et al., 2011), and atranorin (Maulidiyah et al., 2016a).

The urgency and novelty of this study is the importance of exploring secondary metabolite compounds from mosses, such as Teloschistes flavicans, as a natural medicine to treat several human diseases, especially for their antidiabetic activity. We present the exploration of a bioactive compound (vicanicin) and observe the antidiabetic activity potential from lichen $T$. flavicans. It contains the chemical structures of chlorodepsidone, fatty acids, and polysaccharides present in apo-symbiotically cultured myco- and photobionts in the intact thallus and potential for the antidiabetic agent through the inhibitory activity of carbohydrate hydrolysis enzymes, namely $\alpha$-amylase and $\alpha$-glucosidase (Bate et al., 2018; Reis et al., 2005; Ruthes et al., 2008; Umeno et al., 2016).

From the literature reviews, we observed more than 22 lichen extracts have the potential as antidiabetics, likes Everniastrum cirrhatum, Usnea sinensis, Ramalina conduplicans Vain., $R$. hossei, R. sinensis, Parmotremapseudo tinctorum, Flavoparmelia caperata, Physcia aipolia, Heterodermia leucomela, Herpothallon sp., P. Reticulatum, P. tinctorum, U. articulate, R. pollinaria, R. hyrcana, Cladoniarei, P. chinense, Punctelia subrudecta, Punctelia borreri, Hyperphysciaadglutinata, and Peltigera praetextata (Hengameh et al., 2016; Salin Raj et al., 2014; Shivanna et al., 2015; Valadbeigi and Shaddel, 2016; Vinayaka et al., 2013). The extracted lichen and bioactive compounds acted as antidiabetics based on the polyphenol compound group (Thadhani and Karunaratne, 2017). Based on the potential of lichens as natural phytopharmaceuticals, it is necessary to examine the bioactivity compounds from lichen $T$. flavicans which are still underreported in the chemical compounds for its application as antidiabetic. The $\alpha$-glucosidase inhibitory activity is seen as one of the most effective therapeutic approaches in reducing blood glucose levels.

\section{EXPERIMENTAL METHOD}

\section{Extraction of lichen T. flavicans}

A sample of lichen $T$. flavicans was collected from the pine forest in Latimojong Village, Pasui District, Enrekang Regency, South Sulawesi, Indonesia. It was cleaned, dried, and mashed to eliminate the impurities. Then, it was weighed $(560 \mathrm{~g})$ and extracted by using acetone solvent (Merck, Germany) for $3 \times$ 24 hourss (maceration process). Every 24 hours, the lichen extract was filtered to separate the filtrate and residue. This technique was repeated three times and the aim of the high-extraction process was to get the extracted lichen compound. The acetone extract was separated by using a rotary vacuum evaporator to produce high concentrates.

\section{Separation and purification}

The lichen extract was tested by using the thin layer chromatography (TLC) method to identify and determine variations in eluent ratios that can be used in gravity column chromatography (GCC) (Table 1), with a column size of $50 \mathrm{ml}$ and a diameter of $2 \mathrm{~cm}$. The preparation of GCC was carried out by weighing $160 \mathrm{~g}$ of silica gel mixed with n-hexane solvent (Merck, Germany) and put in a GCC tube. On the other hand, the lichen extract was impregnated by weighing as much as $6 \mathrm{~g}$ containing silica gel in a ratio of 1: $1 \mathrm{w} / w$. The sample was eluted in a GCC tube in a solvent gradient as shown in Table 1. Every $250 \mathrm{ml}$ of the lichen extract was put into a vial glass and evaporated to observe the crystal product. After that, 27 eluents were collected and tested on a TLC plate to review specific color spot by calculating the Rf value under ultraviolet (UV) irradiation at 254 and $365 \mathrm{~nm}$, to determine if it has produced the specific color spot that provides a description of secondary metabolites found.

\section{Identification of the bioactive compound}

The isolated compound was analyzed using liquid chromatography-mass spectroscopy (LC-MS) (LCMS 8060 System) to review the molecular weight and provide the structural identity of each component with high molecular specificity and detection sensitivity. Also, Fourier-transform infrared spectroscopy (FTIR) (Shimadzu IR Affity-1S system) was used to observe a typical absorption band at the wavenumber and confirmed using 1D-nuclear magnetic resonance [(NMR) $(1 \mathrm{H}$ and 13C)] (JEOL JNM ECA 500). Referring to these data, we interpret by comparison with the literature reviews.

\section{Bioactivity test}

Toxicity test for A. salina leach shrimp larvae

Initial testing to overview the extracted toxicity compound was applied by using the Meyer method under A. salina Leach (shrimp larvae) (Meyer et al., 1982). The $\mathrm{LC}_{50}$ value is calculated based on the equation: $y=a x+b$, where $y$ states that the shrimp larvae have died 50\% after 24 hours of incubation. Meanwhile, $a$ and $b$ values are data regressions based on a slope with concentration variations as the standard method. Then, we can calculate the value of $\mathrm{x}$ concentration to inhibit the larvae based on $50 \%$ mortality. The substance is active/toxic when the $\mathrm{LC}_{50}$ value is $\leq 1,000 \mu \mathrm{g} / \mathrm{ml}$ (Meyer et al., 1982).

\section{Antidiabetic activity test}

Antidiabetic activity test was conducted by inhibiting the enzyme $\alpha$-glucosidase that has been previously reported by Dewi et al. (2012) and Kim et al. (2008). A positive control using $1 \mathrm{mg}$ of quercetin dissolved in $100 \mu \mathrm{l}$ dimethyl sulfoxide (DMSO) was diluted with four variations of concentration to obtain a standard curve. The positive control was tested with the addition of or without enzyme solution. Meanwhile, the negative controls were prepared without the addition of $5 \mu \mathrm{l}$ DMSO. Finally, we can calculate this with the following equation:

Inhibitory activity $(\%)=$,

where $K$ is the absorbance of the negative control solution, $S$ is the absorbance of test solution or positive control 
solution, and $\left[S=S_{1}\right.$ (absorbance with the addition of enzymes) $S_{0}$ (absorbance without adding enzymes)].

\section{RESULTS AND DISCUSSION}

\section{Isolation of lichen T. flavicans}

The concentrated extract was identified by phytochemical screening to determine the classification of chemical compounds in T. flavicans, which were confirmed as alkaloids, flavonoids, saponins, tannins, and terpenoids, presented in Table 2.

Through the elution process, we obtained 136 eluates with various eluent systems (Table 1). They were tested by using TLC to view patterns of a color spot under UV irradiation at 254 and $365 \mathrm{~nm}$. Several organic compounds containing heterocyclicelectron are conjugated when exposed to UV light. So, we can determine the Rf value on the TLC plate and deduce a single spot.
After recrystallization in fraction 2 (F2) (Table 3) and evaporation, it produced white needle-shaped crystals (Fig. 1).

\section{Identification of the bioactive compound}

White crystal needles were characterized by using the LC-MS/MS chromatogram (Fig. 2), showing a peak at $m / z 383$. We can deduce the molecular weight of the isolated compound to be $383 \mathrm{~g} \mathrm{~mol}^{-1}$. Some chemical compounds of the lichen identified in $m / z 383$ are a depsidone group which enriches the $-\mathrm{OH}$ and $\mathrm{O}$ groups. LC-MS analysis only identifies the molecular weight of a compound to inform the total atoms in the isolated compound.

To predict the chemical groups in the isolated compound, we used FTIR (Fig. 3), which shows that there was a typical absorption band (wavenumber) at $3,511 \mathrm{~cm}^{-1}$ from the $-\mathrm{OH}$ (hydroxyl) group. Then, it showed a C-O stretch of the C-O-C ether group under wavenumbers 2,963 and 1,096 $\mathrm{cm}^{-1}$ (fingerprint

Table 1. The eluent system used in column chromatography and the eluate obtained.

\begin{tabular}{|c|c|c|c|c|c|}
\hline \multirow{2}{*}{ Number } & \multicolumn{3}{|c|}{ Eluent comparison (\%) } & \multirow{2}{*}{ Total eluent volume (ml) } & \multirow{2}{*}{ Eluent arrangement } \\
\hline & n-Hexane & Ethyl acetate & Methanol & & \\
\hline 1. & 100 & 0 & 0 & 2,000 & $1-8$ \\
\hline 2. & 97.5 & 2.5 & 0 & 2,000 & $9-16$ \\
\hline 3. & 95 & 5 & 0 & 3,000 & $17-28$ \\
\hline 4. & 92.5 & 7.5 & 0 & 2,000 & $29-36$ \\
\hline 5. & 90 & 10 & 0 & 1,000 & $37-44$ \\
\hline 6. & 85 & 15 & 0 & 1,000 & $45-48$ \\
\hline 7. & 80 & 20 & 0 & 1,000 & $49-52$ \\
\hline 8. & 75 & 25 & 0 & 1,000 & $53-56$ \\
\hline 9. & 70 & 30 & 0 & 1,000 & $57-60$ \\
\hline 10. & 65 & 35 & 0 & 1,000 & $61-65$ \\
\hline 11. & 60 & 40 & 0 & 1,000 & $66-69$ \\
\hline 12. & 55 & 45 & 0 & 1,000 & $70-73$ \\
\hline 13. & 50 & 50 & 0 & 1,000 & 74-77 \\
\hline 14. & 45 & 55 & 0 & 1,000 & $78-81$ \\
\hline 15. & 40 & 60 & 0 & 1,000 & $82-85$ \\
\hline 16. & 35 & 65 & 0 & 1,000 & $86-89$ \\
\hline 17. & 30 & 70 & 0 & 1,000 & 90-94 \\
\hline 18. & 25 & 75 & 0 & 1,000 & 95-98 \\
\hline 19. & 20 & 80 & 0 & 1,000 & 99-102 \\
\hline 20. & 15 & 85 & 0 & 1,000 & $103-106$ \\
\hline 21. & 10 & 90 & 0 & 1,000 & $107-110$ \\
\hline 22. & 5 & 95 & 0 & 1,000 & 111-114 \\
\hline 23. & 0 & 100 & 0 & 1,000 & $115-118$ \\
\hline 24. & 0 & 90 & 10 & 1,000 & $119-122$ \\
\hline 25. & 0 & 80 & 20 & 1,000 & $123-126$ \\
\hline 26. & 0 & 70 & 30 & 1,000 & $127-131$ \\
\hline 27. & 0 & 60 & 40 & 1,000 & $132-136$ \\
\hline
\end{tabular}

Table 2. Phytochemical screening of the acetone extract for lichen T. flavicans.

\begin{tabular}{ccccccc}
\hline \multirow{2}{*}{ Sample } & \multicolumn{5}{c}{ Compound content } \\
\cline { 2 - 6 } & Alkaloid & Flavonoid & Saponin & Tannin & Terpenoid \\
\hline Lichen T. flavicans extract (acetone extract) & + & + & + & & + & + \\
\hline
\end{tabular}


Table 3. The combined fractions of eluate and fraction mass.

\begin{tabular}{cccc}
\hline Number & Combined eluate & Fraction & Mass fraction (gram) \\
\hline 1 & $1-10$ & F1 & 0.1237 \\
2 & $11-13$ & F2 & 0.1712 \\
3 & $14-18$ & F3 & 0.5757 \\
4 & $19-24$ & F4 & 1.4038 \\
5 & $25-31$ & F5 & 0.4551 \\
6 & $32-44$ & F6 & 0.3348 \\
7 & $45-59$ & F7 & 0.7616 \\
8 & $60-82$ & F8 & 0.4315 \\
9 & $83-91$ & F9 & 0.2469 \\
10 & $92-110$ & F10 & 1.1420 \\
11 & $111-119$ & F11 & 0.1149 \\
12 & $120-136$ & F12 & 1.0652 \\
\hline
\end{tabular}
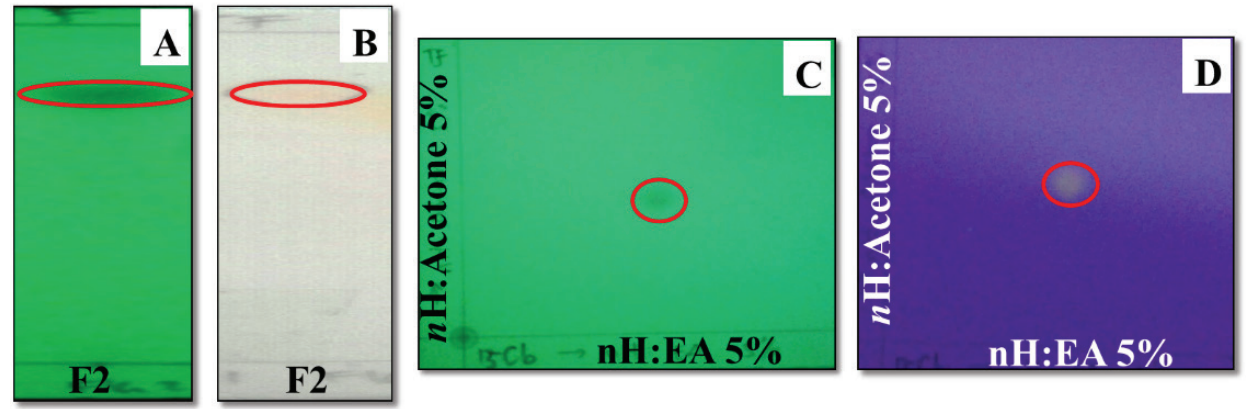

Figure 1. TLC of isolate compound F2: (A) chromatogram under UV $365 \mathrm{~nm}$; (B) after spraying $5 \% \mathrm{H}_{2} \mathrm{SO}_{4}$; (C) 2-dimensional TLC chromatogram under UV $254 \mathrm{~nm}$; and (D) under UV $365 \mathrm{~nm}$.

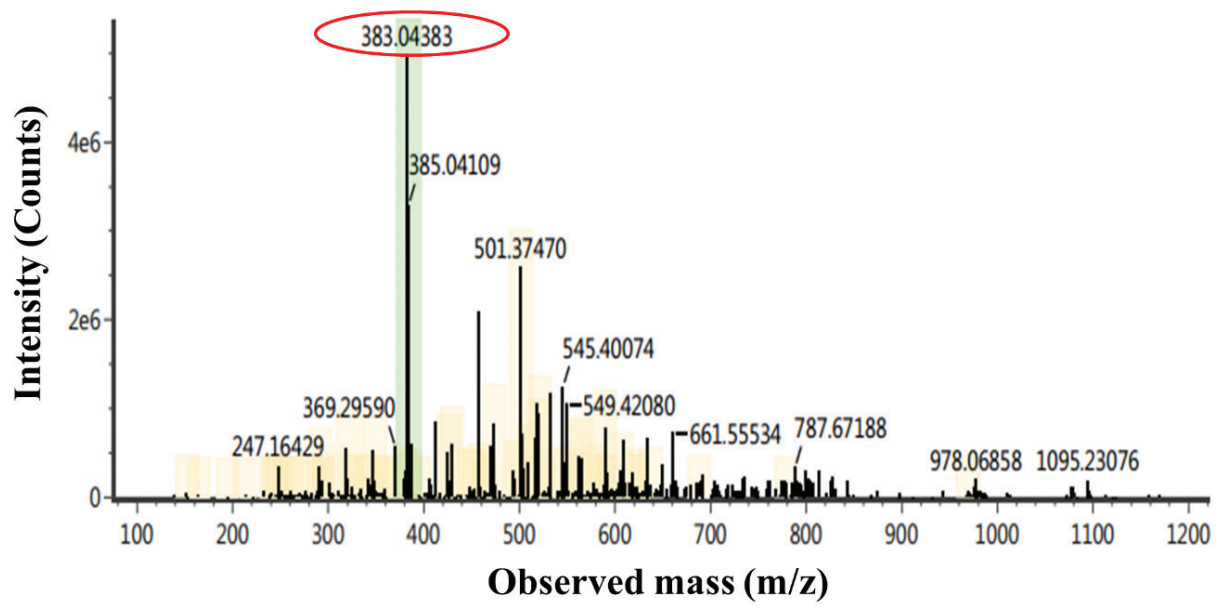

Figure 2. LC-MS/MS chromatogram of the isolated compound.

area). The strong intensity at wavenumber $2,744 \mathrm{~cm}^{-1}$ indicates the carbonyl group $\mathrm{C}=\mathrm{O}$. The presence of an aromatic ring at wavenumber $1,595 \mathrm{~cm}^{-1}$ and buckling bond is confirmed by the cyclic form at wavenumbers 1,437 and $1,359 \mathrm{~cm}^{-1}$ (methylene and methyl groups, respectively). On the other hand, we also discover two halogen groups $(\mathrm{C}-\mathrm{Cl})$ as hydrogen bridges with the $-\mathrm{OH}$ group at wavenumbers of 843 and $729 \mathrm{~cm}^{-1}$. The presence of two chlorine atoms is strengthened by the fragment peaks in LC-MS with $m / z 383$ and 385 with the lower left to right intensity ratio which is characteristic of two chlorine atoms (Kadivar et al., 2011). Based on the FTIR spectrum analysis, the isolated compound had similar absorption data as the vicanicin compound (Huneck and Yoshimura, 1996).

In addition, 1D-NMR was applied to confirm the chemical structure of the isolated compound. The determination of the atomic structure is presented at ${ }^{1} \mathrm{H}$ and ${ }^{13} \mathrm{C}$ based on the 


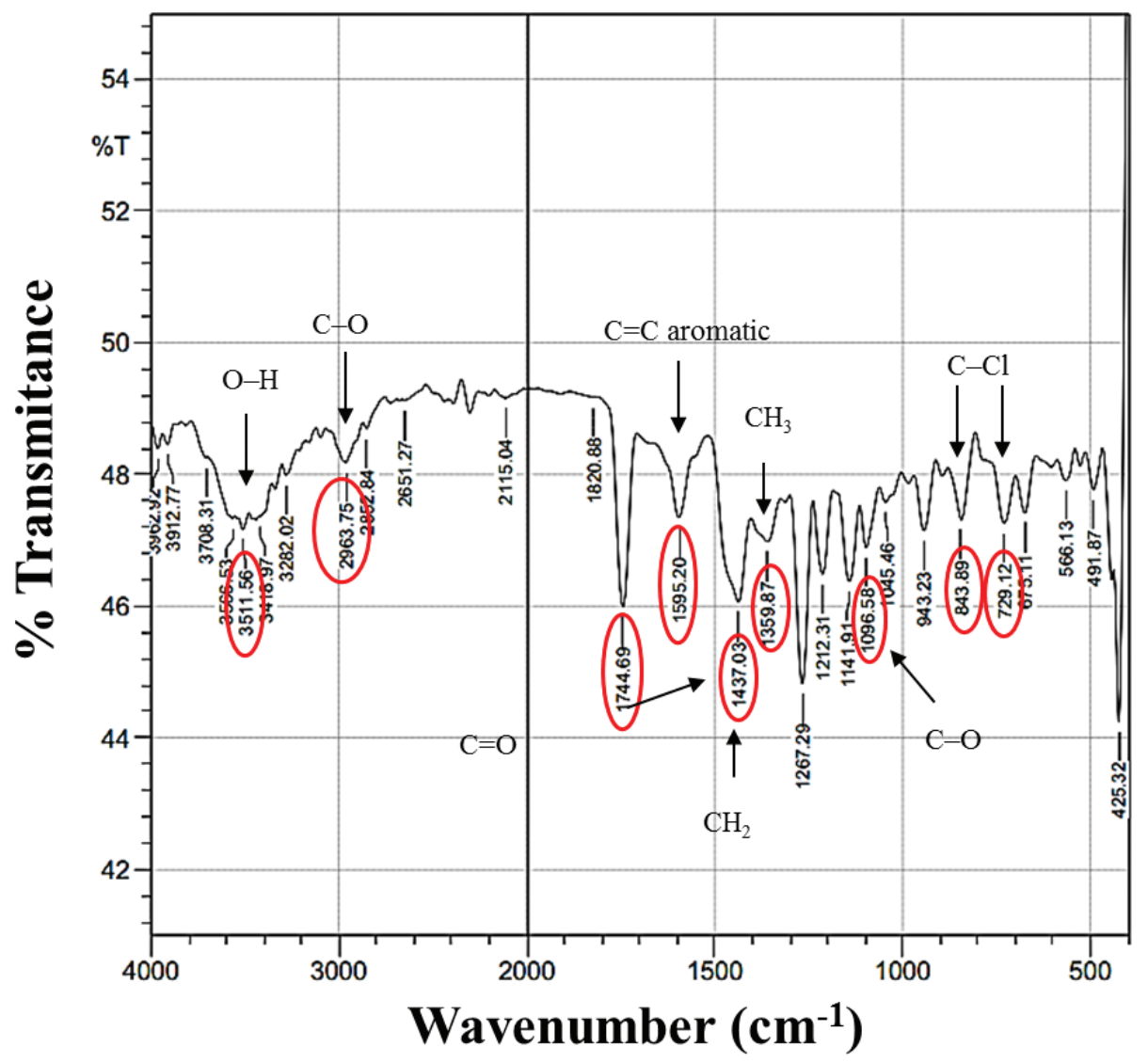

Figure 3. FTIR spectrum of the isolate compound.

position of the $\mathrm{H}$ and $\mathrm{C}$ atoms. According to Figure 4, ${ }^{1} \mathrm{H}-\mathrm{NMR}$ analysis shows that the isolated compound contains 16 hydrogen atoms with the appearance of a single signal. The chemical shift of $\delta \mathrm{H}=6.95 \mathrm{ppm}$ indicates the $-\mathrm{OH}$ group and $\delta \mathrm{H}=3.86 \mathrm{ppm}$ indicates the presence of methoxy group $\left(-\mathrm{OCH}_{3}\right)$ which are attached to the aromatic ring. Then, the chemical shift at 2.55, $2.49,2.422$, and $2.421 \mathrm{ppm}$ shows four methyl groups attached to the aromatics.

Furthermore, an analysis of ${ }^{13} \mathrm{C}$-NMR (Fig. 5) shows that the isolated compound contained 18 carbon atoms at a chemical shift $(\delta C)$ of $60.84 \mathrm{ppm}$, indicating one carbon atom in the methoxy group. The methyl group was confirmed at a chemical shift of $18.59,15.25,11.27$, and $11.26 \mathrm{ppm}$ and the carbonyl group was presented at $\delta \mathrm{C}=162.96 \mathrm{ppm}$, which also appears in the IR spectrum of $1,744 \mathrm{~cm}^{-1}$. Moreover, signals from aromatic groups $(\mathrm{C}=\mathrm{C}$ atom $)$ were confirmed at chemical shifts of 139.00 and $144.50 \mathrm{ppm}$. Based on the interpretation of data compared with several other literature studies (Huneck and Yoshimura, 1996; Sargent et al., 1976), we conclude that the isolated compound was vicanicin with the molecular formula of $\mathrm{C}_{18} \mathrm{H}_{16} \mathrm{Cl}_{2} \mathrm{O}_{5}$.

The number of double bonds and rings in the isolated compound has been determined by the hydrogen deficiency index formula (Wang et al., 2012). The calculation of double bonds or ring number was obtained with an $\mathrm{F}$ value of 10 derived from 1 carbonyl group $(\mathrm{C}=\mathrm{O})$ and 6 double bonds of $\mathrm{C}=\mathrm{C}$ in two aromatic rings. Three rings have been identified wherein two are aromatic rings and one is a nonaromatic ring of the carbonyl group.

Based on the comparison of physical properties and spectrum data of the isolated compound, they have the same data and similarity properties as the vicanicin compound. It is a depsidone group that previously has been isolated from lichen Ramalina javanica Nyl (Pranadita andYuliani, 2019; Sargent et al., 1976). The structural formula of vicanicin is shown in Figure 6.

\section{Bioactivity test}

Information of the bioactivity test inhibiting A. salina Leach and $\alpha$-glucosidase enzyme is shown in Tables 5 and 6 . Based on Table 5, the vicanicin compound has high toxicity against A. salina Leach because it contains cyclic groups, carbonyl groups, and oxygen bridges. Suryani et al. (2019) have reported that the role of the cyclic structure and carbonyl groups can inhibit high toxicity to A. salina Leach.

Table 6 shows the test results of $\alpha$-glucosidase enzyme activity by comparing the performances of quercetin, $T$. flavicans extract, and vicanicin compound. The quercetin as the positive control has a high inhibition compared to the T. flavicans extract and vicanicin with an $\mathrm{IC}_{50}$ value of $4.05,54.05$, and $197.04 \mu \mathrm{g} /$ $\mathrm{ml}$, respectively. However, vicanicin has a lower activity because it does not contain many hydroxyl groups or an active role in inhibiting the $\alpha$-glucosidase enzyme. The $T$. flavicans extract has shown good stability because it still contains a variety of chemical 


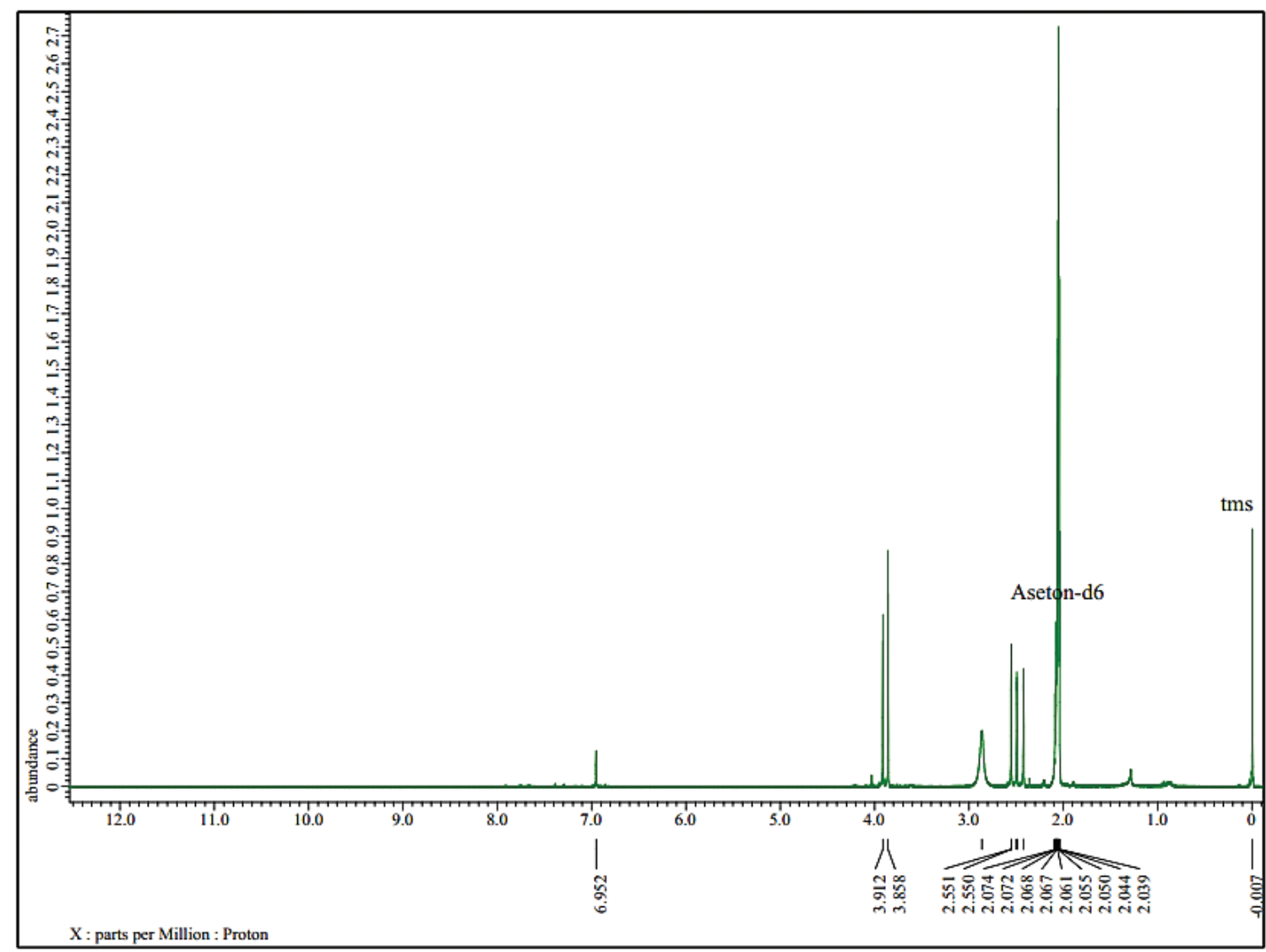

Figure 4. ${ }^{1} \mathrm{H}-\mathrm{NMR}$ spectra of the isolated compound.

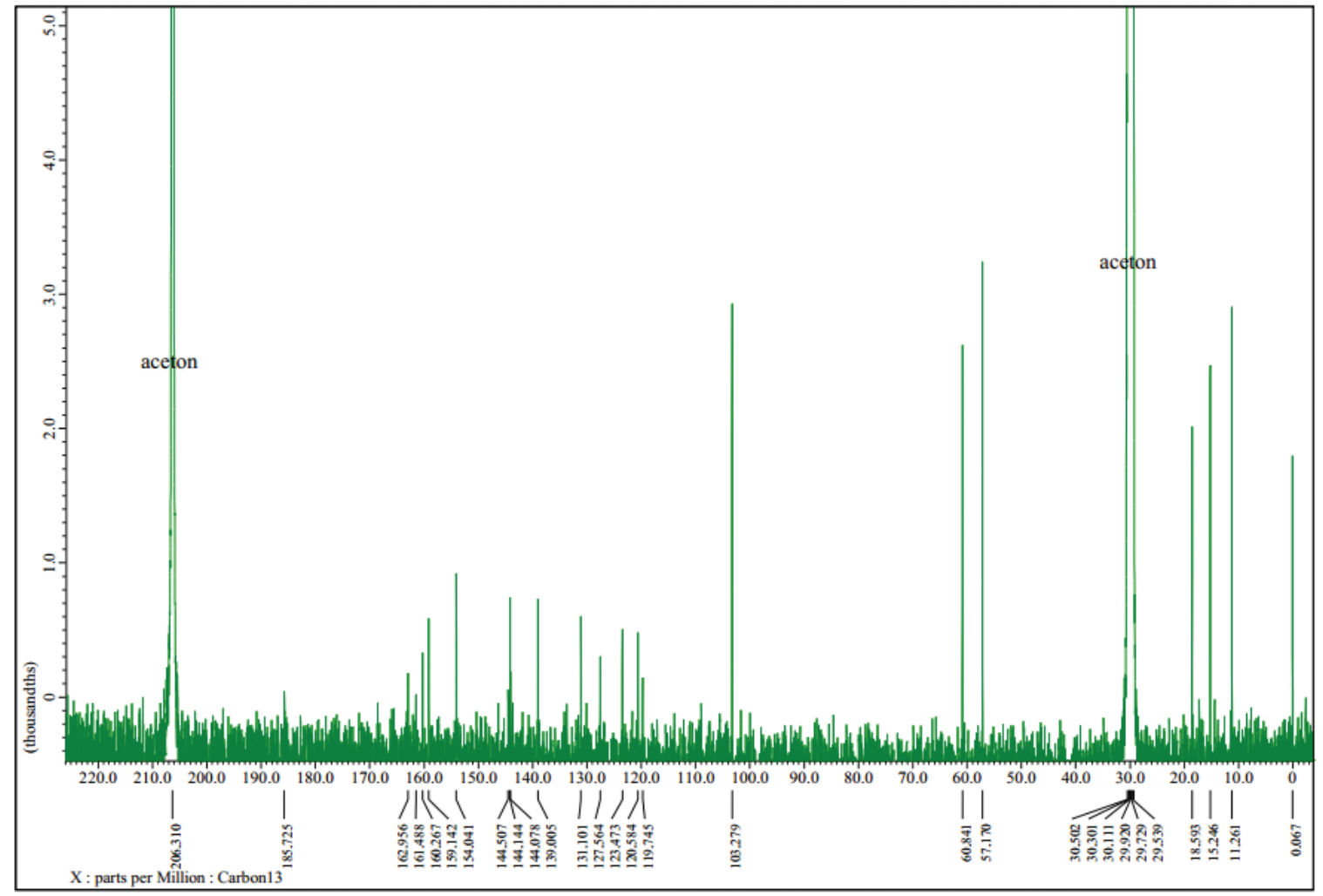

Figure 5. ${ }^{13} \mathrm{C}-\mathrm{NMR}$ spectrum of the isolated compound. 
<smiles>COc1c(C)c2oc3c(C)c(Cl)c(C)c(c3oc2=O)c2c(C)c(O)c(Cl)c12</smiles>

(1D structure of vicanicin compound)

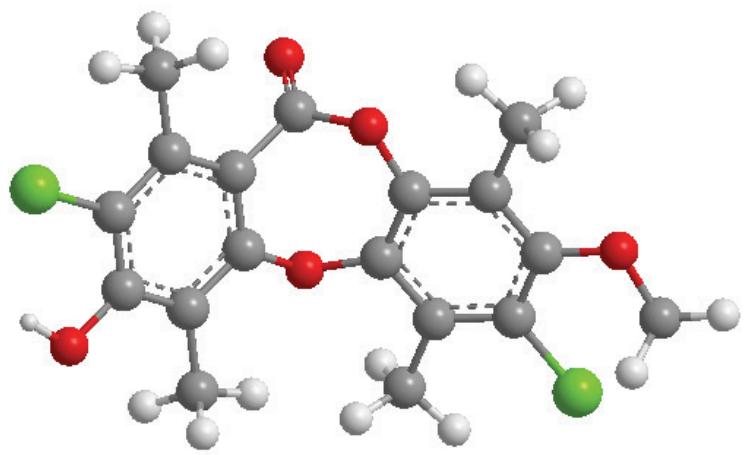

(3D structure of vicanicin compound)

Figure 6. Structure of the vicanicin compound.

Table 4. Comparison of shifting chemical data of ${ }^{1} \mathrm{H}-\mathrm{NMR}$ and ${ }^{13} \mathrm{C}-\mathrm{NMR}$ isolated compound and vicanicin.

\begin{tabular}{ccccc}
\hline \multirow{2}{*}{ Position C } & \multicolumn{2}{c}{ Isolated compound } & \multicolumn{2}{c}{ Vicanicin } \\
\cline { 2 - 5 } & $\boldsymbol{\delta}_{\mathbf{H}}(\mathbf{p p m})$ & $\boldsymbol{\delta}_{\mathbf{C}}(\mathbf{p p m})$ & $\boldsymbol{\delta}_{\mathbf{H}}(\mathbf{p p m})$ & $\left.\boldsymbol{\delta}_{\mathbf{C}} \mathbf{( p p m}\right)$ \\
\hline 1 & & 119.75 & & 115.33 \\
2 & & 160.26 & & 159.52 \\
3 & & 103.28 & & 114.41 \\
4 & $6.95(\mathrm{~s})$ & 159.14 & $6.21(\mathrm{~s})$ & 153.45 \\
5 & & 139.00 & & 138.14 \\
6 & & 119.76 & & 118.68 \\
7 & & 162.96 & & 162.70 \\
8 & $2.422(\mathrm{~s})$ & 11.26 & $2.45(\mathrm{~s})$ & 10.65 \\
9 & $2.49(\mathrm{~s})$ & 18.59 & $2.52(\mathrm{~s})$ & 18.50 \\
$1^{\prime}$ & & 144.50 & & 146.42 \\
$2^{\prime}$ & & 154.04 & & 152.05 \\
$3^{\prime}$ & & 120.59 & & 122.39 \\
$4^{\prime}$ & & 144.08 & & 142.03 \\
$5^{\prime}$ & & 127.56 & & 126.77 \\
$6^{\prime}$ & & 123.47 & & 125.20 \\
$7^{\prime}$ & $2.55(\mathrm{~s})$ & 15.25 & $2.59(\mathrm{~s})$ & 14.74 \\
$8^{\prime}$ & $2.421(\mathrm{~s})$ & 11.27 & $2.41(\mathrm{~s})$ & 10.24 \\
$9^{\prime}$ & $3.86(\mathrm{~s})$ & 60.84 & $3.75(\mathrm{~s})$ & 60.38 \\
\hline
\end{tabular}

Table 5. The toxicity test results of the Brine Shrimp lethality test method on the isolate.

\begin{tabular}{|c|c|c|c|c|c|c|c|c|}
\hline \multirow{2}{*}{ Sample } & \multirow{2}{*}{$\mathrm{K}(\mu \mathrm{g} / \mathrm{ml})$} & \multirow{2}{*}{$\log K$} & \multirow{2}{*}{ Dead } & \multirow{2}{*}{ Alive } & \multicolumn{2}{|c|}{ Accumulation } & \multirow{2}{*}{ Mortality } & \multirow{2}{*}{$\mathrm{LC}_{50}(\mu \mathrm{g} / \mathrm{ml})$} \\
\hline & & & & & M & $\mathrm{H}$ & & \\
\hline \multirow[t]{5}{*}{ Control } & 0 & 0 & 0 & 10 & 0 & 40 & 0 & \\
\hline & 0 & 0 & 0 & 10 & 0 & 30 & 0 & - \\
\hline & 0 & 0 & 0 & 10 & 0 & 20 & 0 & \\
\hline & 0 & 0 & 0 & 10 & 0 & 10 & 0 & \\
\hline & 10 & 1 & 1 & 29 & 1 & 31 & 3.13 & \\
\hline \multirow[t]{2}{*}{ Vicanicin } & 100 & 2 & 28 & 2 & 29 & 2 & 93.55 & 13.07 \\
\hline & 500 & 2.7 & 30 & 0 & 59 & 0 & 100.00 & \\
\hline
\end{tabular}


Tabel 6. Data test results for $\alpha$-glucosidase enzyme inhibitory activity.

\begin{tabular}{lccc}
\hline Sample & Concentration $(\boldsymbol{\mu g} / \mathbf{m l})$ & Inhibition $(\%)$ & IC $_{\mathbf{5 0}}(\boldsymbol{\mu g} / \mathbf{m l})$ \\
\hline \multirow{2}{*}{ Positive control of quercetin } & 12.5 & 75.46 & \\
& 6.25 & 64.46 & 4.05 \\
Lichen T. flavicans extract & 3.125 & 43.43 & \\
& 1.5625 & 25.20 & 54.05 \\
Vicanicin & 100 & 65.49 & \\
& 25 & 49.85 & \\
& 12,5 & 29.99 & 197.04 \\
\hline
\end{tabular}

compounds that synergize to inhibit the $\alpha$-glucosidase enzyme (Li et al., 2005), while vicanicin is a single compound although it is weak in inhibiting the $\alpha$-glucosidase enzyme, making an impact as a potential for antidiabetic activity (Wang et al., 2012). With the chemical structure approach, vicanicin also does not have oxidative properties to inhibit $\alpha$-glucosidase activity which is characterized by presenting oxygen atoms (Stojanovic et al., 2012). According to Gong et al. (2017), secondary metabolites with natural antioxidant properties have the ability to inhibit $\alpha$-glucosidase as a type 2 diabetes treatment.

\section{CONCLUSION}

The secondary metabolite compound vicanicin was isolated from lichen $T$. flavicans, with the molecular formula $\mathrm{C}_{18} \mathrm{H}_{16} \mathrm{Cl}_{2} \mathrm{O}_{5}$. Current information about toxicity of $A$. salina Leach larvae also shows that the antidiabetic potential of $T$. flavicans extract has toxicity to $A$. salina with an $\mathrm{LC}_{50}$ value $<1,000 \mu \mathrm{g} /$ $\mathrm{ml}$, which is $9.38 \mu \mathrm{g} / \mathrm{ml}$. Meanwhile, vicanicin compounds also showed toxicity, with an $\mathrm{LC}_{50}$ value of $13.07 \mu \mathrm{g} / \mathrm{mL}$. The antidiabetic test showed that the $T$. flavicans extract gave the highest inhibition compared to the vicanicin compound, with $\mathrm{IC}_{50}$ values of 54.05 and $197.04 \mu \mathrm{g} / \mathrm{ml}$, respectively. The hydroxyl group contains reactive oxygen compounds in T. flavicans extract which play an important role in inhibiting the larvae of $A$. salina Leach to lyse cell membranes and decide the chemical bonds in the $\alpha$-glucosidase enzyme. This study provides a perspective on the natural products of lichen T. flavicans extract, which have the potential as antidiabetic drugs.

\section{ACKNOWLEDGMENT}

The authors acknowledge the financial support from the DRPM-Ministry of Research, Technology and Higher Education of the Republic of Indonesia under the World Class Research 2020 Grant no. 171/SP2H/AMD/LT/DRPM/2020.

\section{CONFLICT OF INTEREST}

The authors declare that they have no conflicts of interest.

\section{REFERENCES}

Bate PNN, Orock AE, Nyongbela KD, Babiaka SB, Kukwah A, Ngemenya $\mathrm{MN}$. In vitro activity against multi-drug resistant bacteria and cytotoxicity of lichens collected from mount cameroon. J King Saud Univ Sci, 2018; 32(1):614-9.
Dewi RT, Tachibana S, Darmawan A. Antidiabetic and antioxidative activities of butyrolactone I from Aspergillus terreus MC751. World Acad Sci Eng Technol, 2012; 70:882-7.

Gong Y, Qin XY, Zhai YY, Hao H, Lee J, Park YD. Inhibitory effect of hesperetin on $\alpha$-glucosidase: molecular dynamics simulation integrating inhibition kinetics. Int J Biol Macromol, 2017; 101:32-9.

Hengameh P, Rashmi S, Rajkumar HG. In vitro inhibitory activity of some lichen extracts against $\alpha$-amylase enzyme. Eur J Biomed Pharm Sci, 2016; 3:315-8.

Huneck S, Yoshimura I. Identification of lichen substances. In: Identification of lichen substances. Springer, Berlin, Germany, pp 11-123, 1996.

Kadivar MH, Sinha PK, Kushwah D, Jana P, Sharma H, Bapodra A. Study of impurity carryover and impurity profile in Febuxostat drug substance by LC-MS/MS technique. J Pharm Biomed Anal, 2011; 56:749-57.

Kim KY, Nam KA, Kurihara H, Kim SM. Potent $\alpha$-glucosidase inhibitors purified from the red alga grateloupia elliptica. Phytochemistry, 2008; 69:2820-5.

Li Y, Wen S, Kota BP, Peng G, Li GQ, Yamahara J, Roufogalis BD. Punica granatum flower extract, a potent $\alpha$-glucosidase inhibitor, improves postprandial hyperglycemia in Zucker diabetic fatty rats. J Ethnopharmacol, 2005; 99:239-44.

Londoñe-Bailon P, Sánchez-Robinet C, Alvarez-Guzman G. In vitro antibacterial, antioxidant and cytotoxic activity of methanol-acetone extracts from Antarctic lichens (Usnea antarctica and Usnea aurantiacoatra). Polar Sci, 2019; 22:100477.

Lutzoni F, Pagel M, Reeb V. Major fungal lineages are derived from lichen symbiotic ancestors. Nature, 2001; 411:937-40.

Maulidiyah A, Cahyana H, Suwarso WP, Nurdin M. Isolation and structure elucidation of Eumitrin $\mathrm{A}_{1}$ from lichen Usnea blepharea motyka and its cytotoxic activity. Int J Pharm Tech Res, 2015; 8:782-9.

Maulidiyah I, Watu M, Nurdin M. Secondary metabolites identification from lichen Usnea longissima Ach: bioactivity test of antibacterial. Int J Appl Chem, 2016b; 12:347-57.

Maulidiyah M, Cahyana AH, Suwarso WP. A new phenolic compound from acetone extract of lichen Usnea flexuosa Tayl. Indones J Chem, 2011; 11:290-4.

Maulidiyah M, Hasan A, Waode I, Ishmah FAN, Tuty K, Imran, Abdul HW, Thamrin A, Akhmad D. Antifungal potential against Aspergillus flavus: secondary metabolite compound from unique organism of lichen Teloschistes flavicans. Int Res J Pharm, 2018; 9:1-6.

Maulidiyah M, Sabarwati SH, Safutra E, Nurdin ME, Nurdin M Atranorin secondary metabolite from lichen Usnea sp. and its antibacterial activity. Int J Pharma Bio Sci, 2016a; 7:159-69.

Meyer BN, Ferrigni NR, Putnam JE, Jacobsen LB, Nichols DE j, McLaughlin JL. Brine shrimp: a convenient general bioassay for active plant constituents. Planta Med, 1982; 45:31-4. 
Nguyen V-K, Genta-Jouve G, Duong T-H, Beniddir MA, Gallard J-F, Ferron S, Boustie J, Mouray E, Grellier P, Chavasiri W, Pogam PL. Eumitrins CE: Structurally diverse xanthone dimers from the vietnamese lichen Usnea baileyi. Fitoterapia, 2020; 141:104449.

O'Neill E. Mining natural product biosynthesis in eukaryotic algae. Mar Drugs, 2020; 18:90.

Pit'ay MF, Anggraito YU, Ngabekti S. Identifying medicinal plant in local custom nasinoah forest to develop local wisdom based learning material. J Innov Sci Educ, 2019; 8:352-9.

Pranadita KA, Yuliani Y. Potensi ekstrak lichen parmelia sulcata dalam menghambat pertumbuhan bakteri xanthomonas campestris pada tanaman kubis. LenteraBio, 2019; 8(2):162-7.

Rahardi RK. On emblematic meanings of traditional medicinal herbs: local wisdom values in the perspective of culture-specific ecopragmatics. J Arbitrer, 2020; 7:16-28.

Reis RA, Iacomini M, Gorin PAJ, de Souza LM, Grube M, Cordeiro LMC, Sassaki GL. Fatty acid composition of the tropical lichen Teloschistes flavicans and its cultivated symbionts. FEMS Microbiol Lett, $2005 ; 247: 1-6$

Rohman F, Juma Y, Utomo DH, Lestari SR, Arifah SN, Putra WE. Plants diversity as a medicinal plants by the tengger tribe, bromo tengger Semeru National Park, East Java, Indonesia. Eur Asian J Biosci, 2019; 13:2293-8.

Ruthes AC, Komura DL, Carbonero ER, Cordeiro LMC, Reis RA, Sassaki GL, Gorin PAJ, Iacomini M. Polysaccharides present in cultivated Teloschistes flavicans symbiosis: comparison with those of the thallus. Plant Physiol Biochem, 2008; 46:500-5.

Salin Raj P, Prathapan A, Sebastian J, Antony AK, Riya MP, Rani MRP, Biju H, Priya S, Raghu KG. Parmotrema tinctorum exhibits antioxidant, antiglycation and inhibitory activities against aldose reductase and carbohydrate digestive enzymes: an in vitro study. Nat Prod Res, 2014; $28: 1480-4$.

Sargent MV, Vogel P, Elix JA, Ferguson BA. Depsidone synthesis. VII. Vicanicin and norvicanicin. Aust J Chem, 1976; 29:2263-9.

SelvakumarV, Singh S, Kannan K, Annamalai P. Pharmaceutically important metabolites from marine fungi. In: Bioactive natural products in drug discovery. Springer, Berlin, Germany, pp 411-425, 2020

Shivanna R, Parizadeh H, Garampalli RH. Screening of lichen extracts for in vitro antidiabetic activity using alpha amylase inhibitory assay. Int J Biol Pharm Res, 2015; 6:364-7.

Sosilawaty M. Identifying the diversity of orchids in the Sebangau National Park in Central Kalimantan. Int J Adv Res Eng Technol, $2020 ; 11: 185-91$
Stojanovic G, Stojanovic I, Smelcerovic A. Lichen depsidones as potential novel pharmacologically active compounds. Mini Rev Org Chem, 2012; 9:178-84.

Suryani A, Dini I. Usnic acid derivate from Usnea sp. and bioactivity against arthemia salina leach. Mater Sci Forum, 2019, 967:45-50.

Thadhani VM, Karunaratne V. Potential of lichen compounds as antidiabetic agents with antioxidative properties: a review. Oxid Med Cell Longev, 2017; 2017:2079697.

Umeno A, Horie M, Murotomi K, Nakajima Y, Yoshida Y. Antioxidative and antidiabetic effects of natural polyphenols and isoflavones. Molecules, 2016; 21:708.

Valadbeigi T, Shaddel M. Amylase inhibitory activity of some macrolichens in Mazandaran province, Iran. Physiol Pharmacol, 2016; 20:215-9

Vinayaka KS, Karthik S, Nandini KC, Kekuda PTR. Amylase inhibitory activity of some macrolichens of Western Ghats, Karnataka, India. Indian J Nov Drug Deliv, 2013; 5:225-8.

Wang Y, Huang S, Shao S, Qian L, Xu P. Studies on bioactivities of tea (Camellia sinensis L.) fruit peel extracts: antioxidant activity and inhibitory potential against $\alpha$-glucosidase and $\alpha$-amylase in vitro. Ind Crops Prod, 2012; 37:520-6.

Yanuar A, Mun'im A, Lagho ABA, Syahdi RR, Rahmat M, Suhartanto H. Medicinal plants database and three dimensional structure of the chemical compounds from medicinal plants in Indonesia. Int J Comp Sci, 2011; 8(1):180-3.

Yuniati E, Indriyani S, Batoro J, Purwanto Y. The potential of ethnozoology in traditional treatment of bada ethnic in lore lindu biosphere reserve in central sulawesi. In IOP Conference Series: Earth and Environmental Science. IOP Publishing, Bristol, UK, 2019, p 12041.

\section{How to cite this article:}

Maulidiyah M, Darmawan A, Hasan A, Wibowo D, Salim LOA, Ansharullah A, Mustapa F, Nurdin IFA, Nurdin M. Isolation, structure elucidation, and antidiabetic test of vicanicin compound from lichen Teloschistes flavicans. J Appl Pharm Sci, 2020; 10(11):001-009. 